\title{
Deteksi Batik Parang Menggunakan Fitur Co-Occurrence Matrix Dan Geometric Moment Invariant Dengan Klasifikasi KNN
}

\author{
Ni Luh Wiwik Sri Rahayu G \\ Magister IImu Komputer, Universitas Pendidikan Ganesha Singaraja \\ arya.krishna110610@gmail.com
}

\begin{abstract}
Abstrak
Motif batik merupakan suatu dasar atau pokok suatu pola gambar yang merupakan pusat suatu rancangan gambar sehingga makna dari tanda, simbol atau lambang dibalik motif batik tersebut dapat diungkapkan. Identifikasi secara visual memerlukan skill penglihatan dan pengetahuan dalam mengklasifikasikan pola yang terbentuk dari citra batik. Kurangnya media informasi yang dibuat tentang motif batik menjadikan masyarakat luas kurang mendapatkan informasi tentang motif batik. Berdasarkan hal tersebut penelitian ini dilakukan guna mengimplementasikan identifikasi secara visual ke dalam komputer yang dapat membantu dan memudahkan dalam mengidentifikasi jenis batik. Pengenalan citra batik dengan menggunakan metode Cooccurrence Matrix sebagai ekstraksi ciri tekstur dan Geometric Moment Invariant dan pengklasifikasian citra batik dengan menggunakan $K$ Nearest Neighbor. menghasilkan nilai akurasi yang diperoleh dengan metode Geometric Moment Invariant lebih baik dalam mengenali pola batik Parang yang termasuk jenis batik geometric yaitu $80 \%$ dibandingkan dengan hasil pada metode Co-occurence Matrix yaitu $70 \%$.
\end{abstract}

Kata kunci: Motif batik, identifikasi. Co-occurrence Matrix, Geometric Moment Invariant, $\mathrm{K}$ Nearest Neighhbor.

\begin{abstract}
Batik motifs are the base or the blueprint of batik patterns which serve as the core of the batik image design, and therefore the meaning of a sign, symbol or logo in a batik work can be revealed through its motifs. Visual identification requires visual skills and knowledge in classifying patterns formed in a batik image. Lack of media providing information on batik motifs makes the public unable to have sufficient information about batik motifs. Looking at this phenomenon, this study is conducted in order to perform visual identification using a computer that can assist and facilitate in identifying the types of batik. The methods used for batik image recognition are the Co-occurrence Matrix method to provide extraction of batik texture features, and the Geometric Moment Invariant method, while K Nearest Neighbor is used to classify batik images. The results on the accuracy values obtained reveal that the of $80 \%$, compared to the accuracy value result using the Co-occurrence Matrix method that is $70 \%$.
\end{abstract}

Keywords: batik motifs, identification, Co-occurrence Matrix, Geometric Moment Invariant, $K$ Nearest Neighhbor.

\section{Pendahuluan}

Negara Indonesia merupakan negara yang terdiri dari aneka ragam pulau,suku bangsa,bahasa dan budaya. Salah satu yang menjadi ciri khas Indonesia dimata dunia adalah batik. Batik merupakan warisan asli budaya Indonesia yang tidak hanya indah secara visual, lebih jauh batik memiliki nilai filosofi yang tinggi dan syarat akan makna. Batik Indonesia hampir saja diklaim oleh negara lain akan tetapi pada tanggal 2 Oktober 2009 UNESCO telah mengakui bahwa batik merupakan hak kebudayaan intelektual bangsa Indonesia.

Motif batik merupakan suatu dasar atau pokok suatu pola gambar yang merupakan pusat suatu rancangan gambar sehingga makna dari tanda, simbol atau lambang dibalik motif batik tersebut 
dapat diungkapkan. Identifikasi secara visual memerlukan skill penglihatan dan pengetahuan dalam mengklasifikasikan pola yang terbentuk dari citra batik. Kurangnya media informasi yang dibuat tentang motif batik menjadikan masyarakat luas kurang mendapatkan informasi tentang motif batik. Berdasarkan hal tersebut penelitian ini dilakukan guna mengimplementasikan identifikasi secara visual ke dalam komputer yang dapat membantu dan memudahkan dalam mengidentifikasi jenis batik.

Berbagai jenis batik yang ada di Indonesia memiliki suatu pola yang khusus satu sama lainnya. Seperti halnya dengan batik Parang yang berasal dari daerah D.I Yogyakarta. Batik Parang memiliki karakteristik familiar sebagai pola pedang atau keris oleh orang luar. Parang sendiri diartikan sebagai pertarungan antara manusia melawan kejahatan dengan cara mengendalikan keinginan mereka sehingga mereka menjadi mulia, bijaksana dan akan menang. Parang Rusak memiliki ciri dari segi warna umumnya putih tulang pada bagian dalam, dan bergaris coklat, warna agak gelap dan warna alami. Motif perulangan, agak miring dan arah bolak balik,garisgaris lengkung.

Beberapa penelitian sebelumnya tentang batik dan klasifikasinya [1] yang salah satunya telah dilakukan oleh Dhani Pratikaningtyas dengan menggunakan Metode Transformasi Paket Wavelet, pada penelitian ini citra batik diklasifikan ke dalam 6 kelas yaitu parang, nitik, megamendung, tambal, buket dan garuda. Metode Wavelet yang digunakan dalam penelitiannya adalah Wavelet $D b-2$, Wavelet $D b-3$ dan Wavelet Coif-1. Hasil yang diperoleh dari penelitian menunjukan metode Wavelet $D b-2$, memiliki kesalahan paling sedikit dibanding dengan filter atau jenis Wavelet yang lain. Kesalahan pengklasifikasian pada penelitian ini disebabkan oleh beberapa hal antara lain adanya kemiripan secara visual yaitu kesalahan identifikasi yang dapat terjadi apabila terdapat citra pada basis data yang memiliki ciri-ciri atau pola informasi yang sangat dekat atau hampir sama (mirip). Dan adanya cacat pada citra, meskipun secara visual tidak mirip tetapi kedekatan ciri-ciri atau pola informasi bisa terjadi karena adanya cacat pada citra. Berdasarkan uji coba yang telah dilakukan sebelumnya dapat ditarik kesimpulan motif yang berbeda akan mempunyai nilai energi yang berbeda pula, demikian pula saat dilakukan rotasi akan menghasilkan suatu nilai energi yang tidak sama dengan tekstur tanpa rotasi.

\section{Metodologi Penelitian}

\subsection{Akuisisi Data}

Akuisisi data merupakan proses pengubahan data dari analog menjadi citra RGB dengan bantuan kamera digital dan citra akan disimpan dalam format .jpg yang kemudian akan diproses ke tahapan preprocessing.

\subsection{Preprocessing}

Citra batik yang dihasilkan dari proses akuisisi data akan dilakukan proses pemotongan untuk memudahkan proses selanjutnya dengan ukuran $256 \times 256$ pixel. Contoh citra yang belum dicrop dapat dilihat pada gambar di bawah ini.

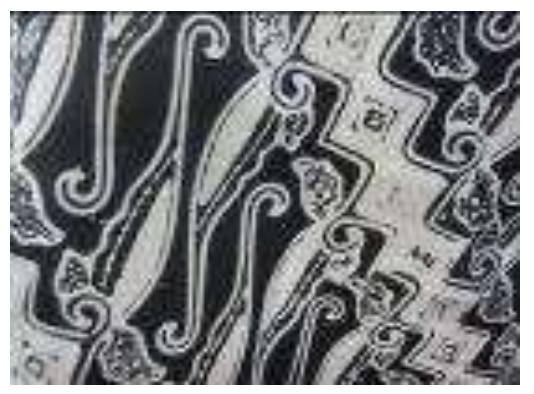

Gambar 1. Citra sebelum di-cropping.

Citra batik yang belum di crop memiliki ukuran pixel yang besar,sehingga untuk mempermudah proses selanjutnya citra di crop dengan ukuran $256 \times 256$ pixel seperti pada gambar dibawah ini. 


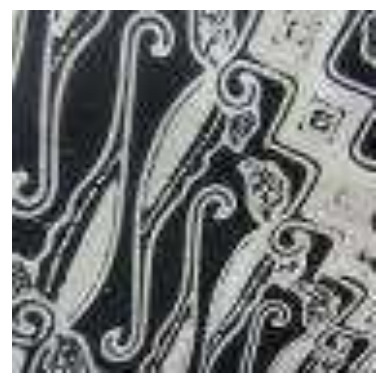

Gambar 2. Citra hasil crop.

\subsection{Ekstraksi Ciri}

Ekstraksi ciri dilakukan menggunakan fitur tekstur citra dan bentuk. Gambar 3 menunjukkan ekstraksi ciri yang digunakan.

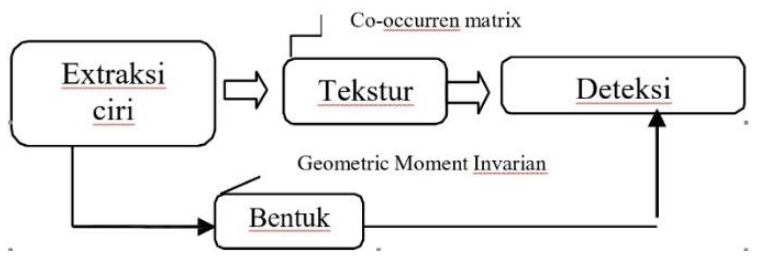

Gambar 3. Ekstraksi Ciri

\subsection{Ekstraksi Ciri Tekstur}

Ekstraksi ciri tektur dilakukan untuk memperoleh ciri citra untuk kemudian diklasifikasikan berdasarkan ciri hasil ekstraksi tersebut. Berikut diagram alir ekstraksi ciri tekstur.

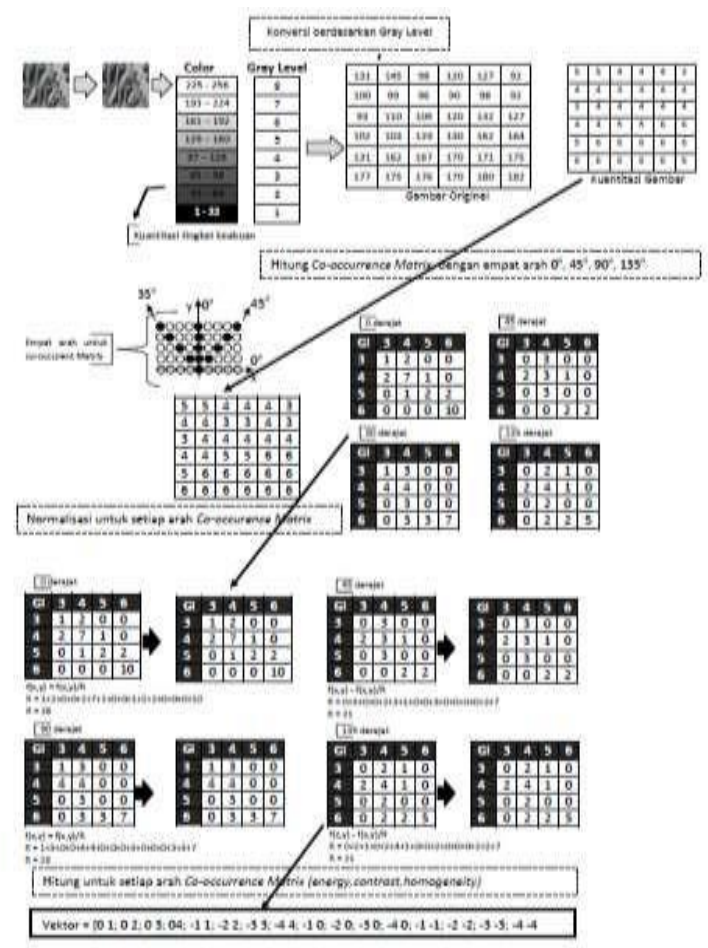

Gambar 4. Diagram Alir Ekstraksi Ciri Tekstur 
Keterangan gambar :

a. Dalam penelitian ini, tingkat keabuan 256 dikuantisasi menjadi $8 \times 8$ Co-occurrence Matrix, tingkat keabuan 1-32 dianggap sebagai 1, maka 33 berikutnya sebagai 2 dan seterusnya.

Tabel 1. Kuantitas tingkat keabuan.

\begin{tabular}{cc}
\hline $\begin{array}{c}\text { Tingkat keabuan dari } \\
\text { sebuah citra }\end{array}$ & $\begin{array}{c}\text { Kuantitas tingkat } \\
\text { keabuan }\end{array}$ \\
\hline $1-32$ & 1 \\
\hline $33-64$ & 2 \\
\hline $65-96$ & 3 \\
\hline $97-128$ & 4 \\
\hline $129-160$ & 5 \\
\hline $161-192$ & 6 \\
\hline $193-244$ & 7 \\
\hline $245-256$ & 7 \\
\hline
\end{tabular}

b. Tentukan Co-occurrence Matrix, yaitu menghitung dengan empat arah $0^{\circ}, 45^{\circ}, 90^{\circ}$, dan $135^{\circ}$. Jadi untuk setiap citra akan didapatkan empat Co-occurrence Matrix [2]

C. Dari hasil perhitungan terhadap empat arah diperoleh $4 \times 16=64$ Co-occurrence Matrix. Untuk mengurangi dimensi dan lamanya waktu komputasi, maka dilakukan perhitungan rata-rata, dengan menggunakan rumus :

$$
f(x, y)=f(x, y) / R
$$

d. Energy, moment, entropy, probability, dihitung untuk setiap Co-occurrence Matrix, untuk lebih menghemat waktu komputasi jumlahk an terlebih dahulu empat nilai masingmasing arah $0^{\circ}, 45^{\circ}, 90^{\circ}$, dan $135^{\circ}$.

\subsection{Ekstraksi Ciri Bentuk}

Tahapan pada proses ekstraksi ciri bentuk dengan metode Geometric Moment Invariant. Pertama segmentasi background untuk memisahkan objek dengan background dari citra, kemudian threshold sehingga menjadi gambar biner, dengan menggunakan tolak ukur pengubahan nilai pixel apakah menjadi 0 (hitam) atau 225 (putih). Hitung moment dan moment pusat menggunakan persamaan:

$$
m_{p q}{ }^{i}=\iint \delta\left(x^{i}\right)^{p}\left(y^{i}\right)^{q} f^{i}\left(x^{i}, y^{i}\right) d x^{i} d y^{i} ; p, q=0,1,2 \ldots
$$

dan

$$
\mu_{p q^{i}}{ }^{i}=\iint \delta\left(x-x_{0}\right)^{p}\left(y-y_{0}\right)^{q} f^{i}(x, y) d x d y ; p, q=0,1,2 \ldots
$$

Selanjutnya moment pusat dinormalisasi menggunakan persamaan :

$$
\eta_{i j}=\frac{\mu_{1 j}}{\left(\mu_{00}\right)^{2}}
$$

kemudian hitung geometric moment ${ }^{\phi_{1}}$ sampai dengan ${ }^{\phi} 4$ untuk menghitung translasi, skala dan rotasi menggunakan persamaan :

$$
\begin{aligned}
& \phi 1=\eta_{20}+\eta_{02} \\
& \phi 2=\left(\eta_{20}+\eta_{20}\right)^{2}+4 \eta_{11}^{2} \\
& \phi 3=\left(\eta_{30}+3 \eta_{12}\right)^{2}+\left(3 \eta_{21}-\eta_{03}\right)^{2} \\
& \phi 4=\left(\eta_{30}+\eta_{12}\right)^{2}+\left(\eta_{21}-\eta_{03}\right)^{2}
\end{aligned}
$$

Diagram alir proses ekstraksi ciri bentuk dapat dilihat pada gambar dibawah ini: 


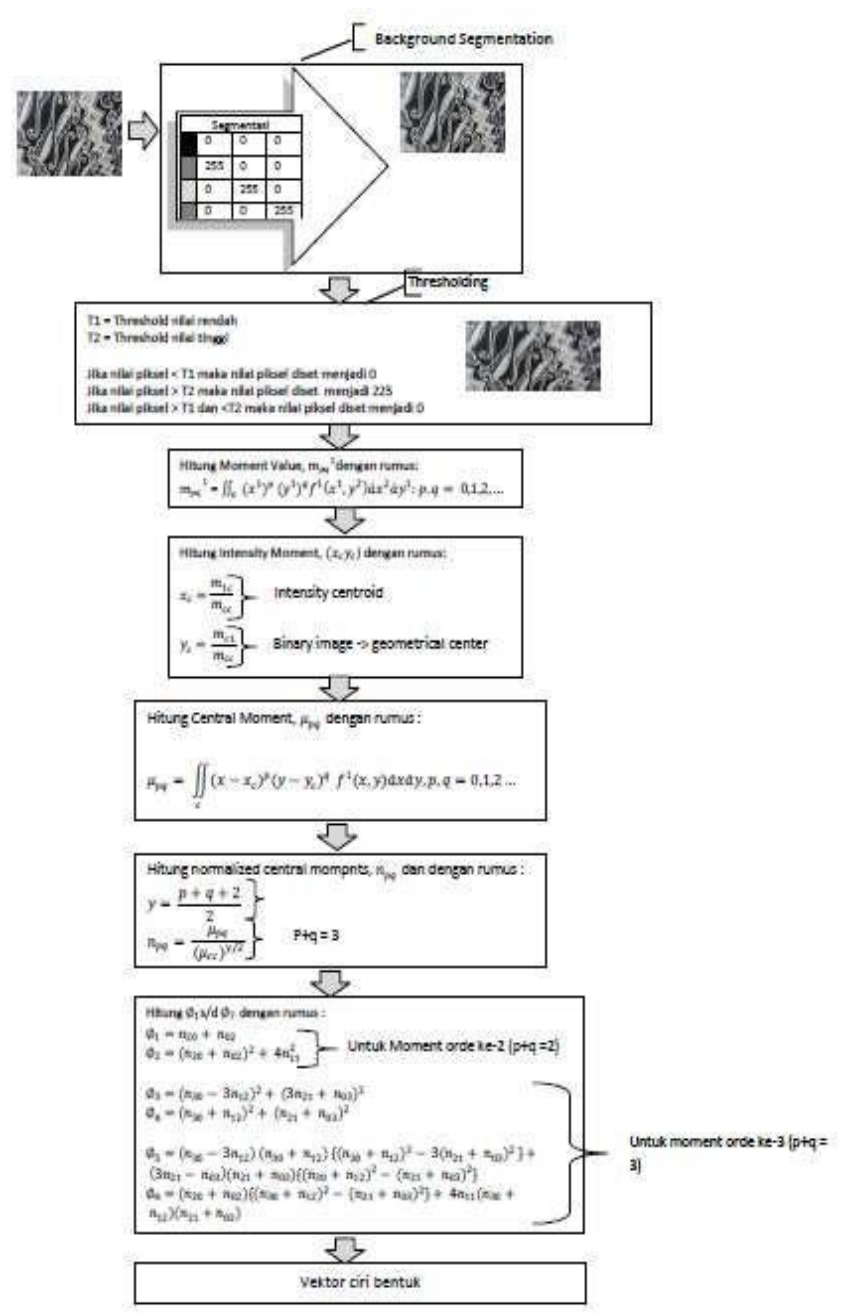

Gambar 5. Diagram Ekstraksi Ciri Bentuk

\subsection{Klasifikasi}

Citra baru yang akan diklasifikasikan dipraolah dan fitur dibuat dari citra uji, kemudian dibandingkan dengan fitur yang berada pada basis data. Metode klasifikasi $K$ Nearest Neighbor digunakan untuk menentukan kelas dari citra batik yang baru. Klasifikasi $K$ Nearest Neighbor dilakukan dengan mencari $k$ buah tetangga terdekat dari data uji dan memilih kelas dengan anggota terbanyak. Dalam hal ini jumlah data/tetangga terdekat ditentukan oleh user yang dinyatakan dengan $k$, misalnya ditentukan $k-6$, maka setiap data testing dihitung jaraknya terhadap data training dan dipilih 6 data training yang jaraknya paling dekat ke data testing. Lalu periksa output atau labelnya masing-masing, kemudian tentukan output mana yang frekuensinya paling banyak. Untuk mendefinisikan jarak antara dua titik yaitu titik pada data training $(\mathrm{x})$ dan titik pada data testing $(\mathrm{y})$ maka digunakan rumus Euclidean.

$$
d(x, y)=\sqrt{\sum_{i=1}^{n}\left(x_{i}-y_{i}\right)^{2}}
$$

Dengan $\mathrm{d}$ adalah jarak antara titik pada data training $x$ dan titik data testing $y$ yang akan diklasifikasi, dimana $x=x_{1}, x_{2}, \ldots x_{i}$ dan $y=y_{1}, y_{2}, \ldots y_{i}$ dan ${ }^{i}$ merepresentasikan nilai atribut serta ${ }^{n}$ merupakan dimensi atribut. Klasifikasi menggunakan Algoritma K-Nearest Neighbor (KNN) dapat dilihat pada Gambar 6 dengan $k=6$. 


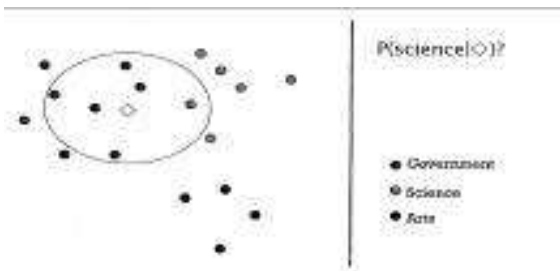

Gambar 6. Klasifikasi K-Nearest Neighbor (KNN)

Langkah-langkah untuk menghitung metode $K$-Nearest Neighbor:

a. $\quad$ Menentukan parameter $k$ (jumlah tetangga paling dekat)

b. Menghitung kuadrat jarak Euclidean (query instance) masing-masing objek terhadap data sample yang diberikan.

c. Kemudian mengurutkan objek -objek tersebut ke dalam kelompok yang mempunyai jarak Euclidean terkecil

d. Mengumpulkan kategori $y$ (Klasifikasi Nearest Neighbor)

e. Dengan menggunakan kategori Nearest Neighbor yang paling mayoritas maka dapat diprediksikan nilai query instance yang telah dihitung

\section{Kajian Pustaka}

\subsection{Batik}

Kata "batik" berasal dari gabungan dua kata bahasa Jawa: "amba", yang bermakna "menulis" dan "titik" yang bermakna "titik". Batik memiliki berbagau macam motof yang bervariasi. Setiap daerah di Indonesia memiliki ciri khas tertentu pada motif batik. Batik memiliki keunikan, keunikan ini terletak pada motif,pakem (cara motif diorganisasi),dan insen-insen (ornamenornamen kecil yang digunakan untuk mengisi ruangan yang kosong diantara motif utama). Motif batik dapat berbentuk geometris maupun non geometris. Motif memiliki peranan penting dalam mendefinisikan filosofi atau arti batik. Motif batik dapat disebut juga corak batik atau pola batik. Motif batik terbagi menjadi dua kelompok besar yaitu :

a. Motif Geometri

1. Motif Parang, motif ini terdiri atas satu atau lebih ragam hias yang tersusun membentuk garis-garis sejajar dengan sudut miring $45^{\circ}$. Terdapat ragam hias bentuk belah ketupat sejajar dengan deretan ragam hias utama pola parang disebut mlinjo. Berikut ini adalah gambar contoh motif batik parang.

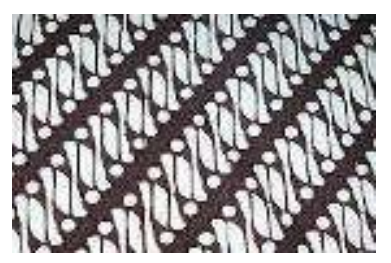

Gambar 7. Batik Parang

2. Motif Ceplok, merupakan motif batik yang didalamnya terdapat gambar-gambar segi empat,lingkaran, dan segala variasinya dalam membuat sebuah pola yang teratur. Berikut ini adalah gambar batik ceplok.

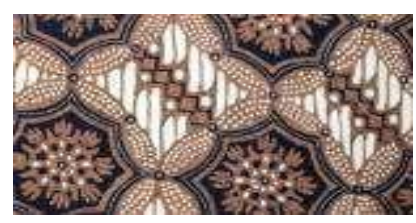

Gambar 8. Batik Ceplok 


\section{b. Motif Non Geometri}

1. Motif Semen, ragam hias yang merupakan ciri pola semen adalah meru. Hakikat meru adalah lambang gunung atau tempat tumbuhan bertunas atau bersemi sehingga motif ini disebut semen, yang diambil dari kata dasar semi. Berikut adalah gambar dari contoh motif batik semen.

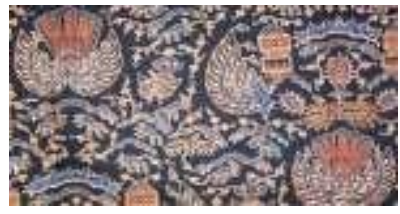

Gambar 9. Batik Semen

2. Motif Lung-Lungan, sebagaian besar motif lung-lungan mempunyai ragam hias serupa dengan motif semen. Berbeda dengan pola semen, ragam hias utama lung- lungan tidak selalu mengandung ragam hias meru.

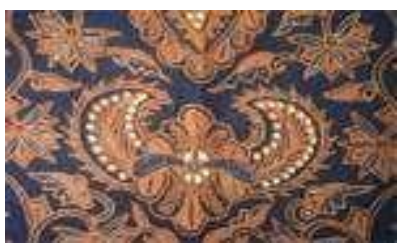

Gambar 10. Batik Lung-Lungan

\subsection{Pengenalan Pola}

Secara umum pengenalan pola (pattern recognition) adalah suatu ilmu kuantitatif fitur atau sifat utama dari suatu objek [2]. Pengenalan pola terdapat beberapa tahapan [3].

a. Pattern pertama kali ditangkap oleh sensor untuk dianalisa dan didapat berbagai fiturnya.

b. Setelah mendapat informasi dari fitur yang ada maka selanjutnya adalah melakukan generate terhadap fitur.

c. Tidak semua fitur yang didapat dari sensor digunakan untuk pengenalan pola tersebut. Maka langkah selanjutnya adalah dengan memilih fitur yang tepat untuk pengklasifikasian objek tersebut.

d. Selanjutnya mendesain pengklasifikasian, tipe nonlinearity bagaimana yang diadopsi, dan bagaimana mendapatkan kriteria/fitur yang optimal.

e. Ketika terjadi error dalam pengklasifikasian maka terjadi ketidak beresan dalam sistem maka sistem perlu diadakan evaluasi.

\subsection{Ekstraksi Ciri}

Ekstrasi ciri merupakan proses pengideksan suatu basis data citra dengan isi nya. Komponen vektor ciri dihitung dengan pemrosesan citra dan teknik analisis serta digunakan untuk membandingkan citra yang satu dengan citra yang lainnya. Ekstraksi citra diklasifikasikan kedalam tiga jenis yaitu low-level, middle level dan high level. Low level feature merupakan ekstraksi ciri berdasarkan isi visual seperti warna dan tekstur, middle level feature merupakan ekstraksi berdasarkan wilayah citra yang ditentukan dengan segmentasi, sedangkan high level feature merupakan ekstrasi ciri berdasarkan informasi semantik yang terkandung dalam citra [4].

\subsection{Co-ocurrence Matrix}

Co-occurrence Matrix mempunyai sekumpulan informasi tentang derajat keabuan (intensitas) suatu piksel dengan tetangganya, pada jarak dan orientasi yang tepat. Ide dasarnya adalah untuk men-scan citra untuk mencari jejak derajat keabuan setiap dua buah piksel yang dipisahkan dengan jarak $\mathrm{d}$ dan sudut 0 yang tetap, tetapi umumnya tidak hanya satu jarak atau 
sudut saja cukup untuk menggambarkan ciri tekstur citra tersebut, sehingga harus digunakan lebih dari satu jarak dan arah. Umumnya digunakan empat arah horizontal, vertical dan dua arah diagonal.

\subsection{Ekstraksi Ciri Bentuk}

Ciri bentuk suatu gambar dapat ditentukan oleh tepi (sketsa), atau besaran moment dari suatu gambar. Deteksi tepi merupakan operasi yang digunakan untuk mendeteksi garis tepi (edges) yang membatasi dua wilayah citra homogen yang memiliki tingkat kecerahan yang berbeda. Momen dapat menggambarkan suatu objek dalam hal area, posisi, orientasi dan parameter terdefinisi lainnya.

\subsection{Klasifikasi}

Klasifikasi adalah proses menemukan model untuk membedakan kelas atau konsep agar model yang diperoleh dapat digunakan untuk mengetahui kelas dari objek yang belum diketahui karakteristiknya. Proses klasifikasi terbagi atas dua tahapan, yaitu learning dan testing. Pada tahapan learning, sebagian data yang telah diketahui kelas datanya (training set) digunakan untuk membentuk model. Selanjutnya pada tahapan testing, model dengan sebagian data lainnya (test set) untuk mengetahui akurasi dari model tersebut.

\section{Percobaan dan Hasil}

Percobaan 1 pada penelitian ini menggunakan data set dengan ukuran citra 256x256 pixel dan $512 \times 512$ pixel sebanyak 120 citra. Jumlah untuk citra latih sebanyak 70 citra dan jumlah untuk uji coba sebanyak 50 citra dan pada percobaan 2 akan digunakan dataset sebanyak 100. Jumlah data latih dan data uji coba yaitu 50 citra. Proses memasukkan citra dengan fitur Co-occurence Matrix sebagai data latih untuk disimpan di dalam basis data

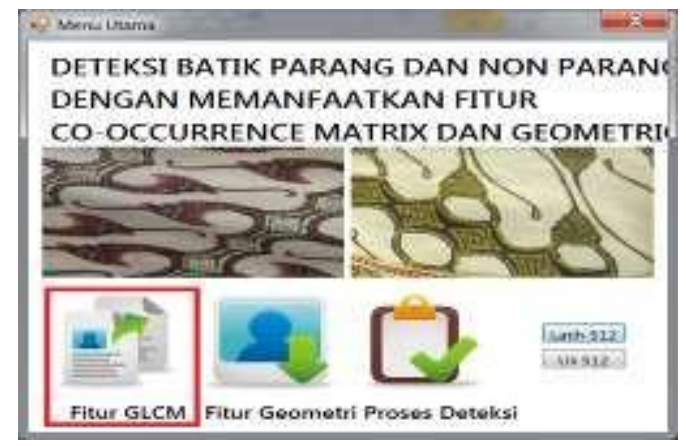

Gambar 11. Tampilan Awal

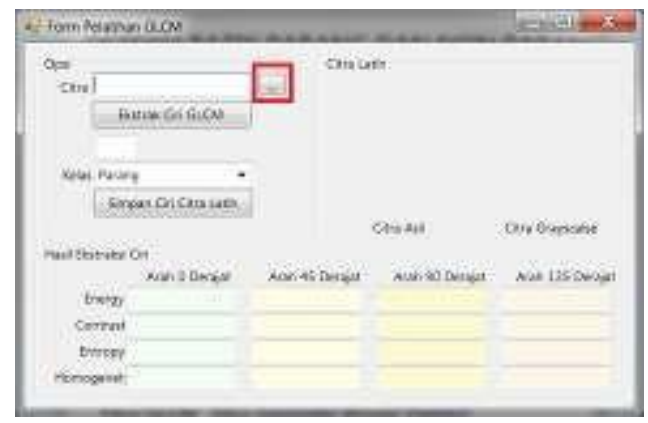

Gambar 12. Proses Pengambilan Citra Latih untuk Co-occurrence Matrix

Selanjutnya citra untuk data latih di load dan dilakukan ekstraksi ciri tekstur dengan fitur Cooccurence Matrix dengan arah $0^{\circ}, 45^{\circ}, 90^{\circ}$ dan $135^{\circ}$ serta penentuan kelas dari citra dan hasilnya disimpan di dalam basis data. 


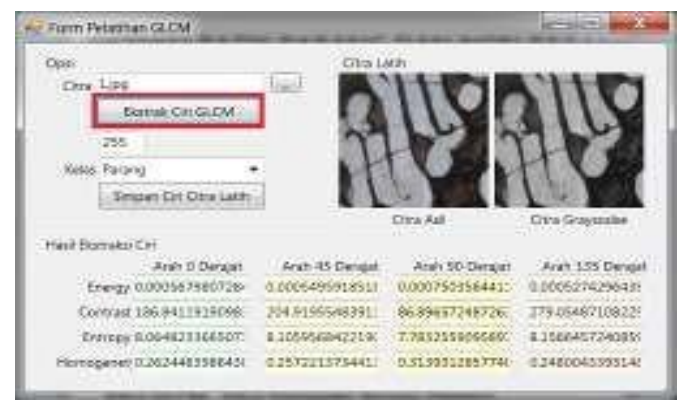

Gambar 13. Hasil Ekstraksi Ciri Tekstur pada Citra Latih

Proses memasukkan citra dengan fitur Geometric Moment Invariant sebagai data latih yang kemudian dimasukkan kedalam basis data:

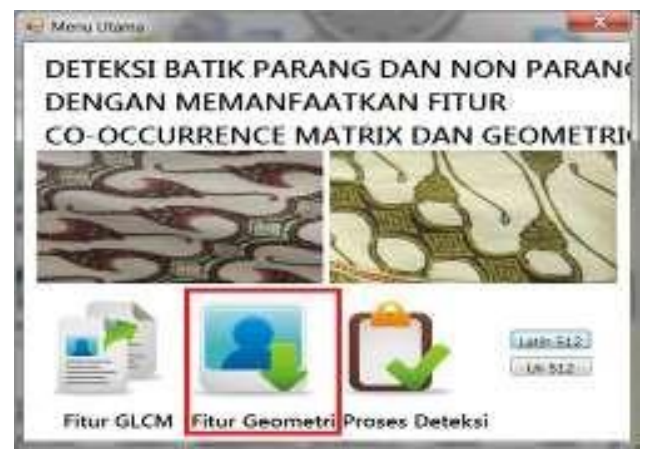

Gambar 14. Tampilan Awal Fitur Geometric Moment Invariant.

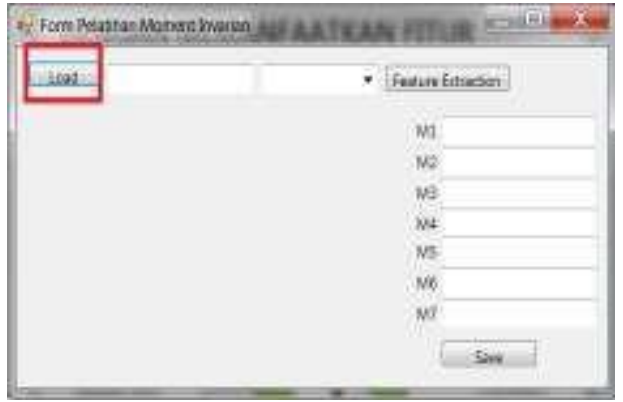

Gambar 15. Proses Pengambilan Citra Latih untuk Geometric Moment Invariant.

Selanjutnya citra untuk data latih di load dan dilakukan ekstraksi ciri bentuk dengan fitur Geometric Moment Invariant serta penentuan kelas dari citra dan hasilnya disimpan di dalam basis data. 


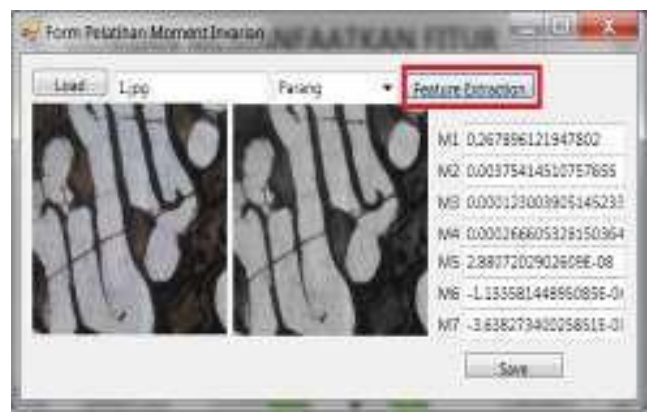

Gambar 16. Hasil Ekstraksi Ciri Bentuk pada Citra Latih

Setelah data latih selesai diproses maka selanjutnya akan dilakukan pengujian untuk citra batik. Citra yang diambil akan di uji dengan arah $0^{\circ}, 45^{\circ}, 90^{\circ}$ dan $135^{\circ}$ dan dengan rentang nilai $\mathrm{k} 1$ 10 untuk klasifikasi $K$ Nearest Neighbor.

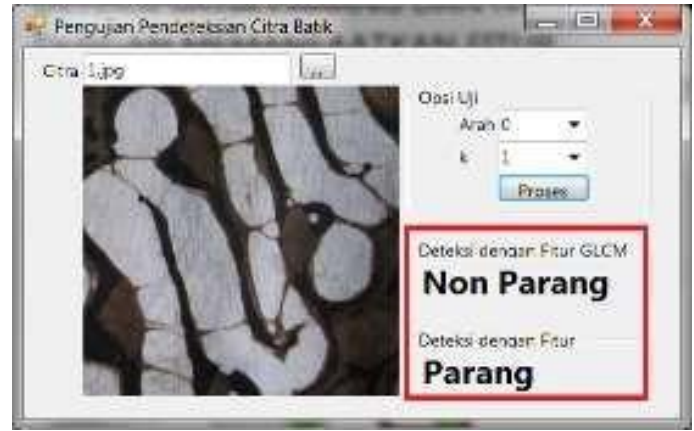

Gambar 17. Hasil Pengujian Deteksi Batik Parang

Dengan menggunakan rumus perhitungan akurasi seperti berikut:

$$
\text { Akurasi }=\frac{\text { Ladtauj yang dhenall }}{\sum \text { data uji }} \times 100 \%
$$

Maka diperoleh hasil pada percobaan 1 dan 2 dengan ukuran citra 256x256 pixel dengan $d=1$

Tabel 2. Hasil Percobaan dengan Citra 256x256 pixel.

\begin{tabular}{llll}
\hline Jumlah Data Latih & Jumlah Data Uji & $\begin{array}{l}\text { Co-occurrence } \\
\text { Matrix }\end{array}$ & $\begin{array}{l}\text { Geometric Moment } \\
\text { Invariant }\end{array}$ \\
\hline 70 & & $66,5 \%$ & $82,6 \%$ \\
\hline 50 & 50 & $65,7 \%$ & $79 \%$ \\
\hline
\end{tabular}

Dari tabel diatas dengan ukuran citra 256x256 pixel dan jumlah data latih 70 citra dan jumlah data uji 50 citra nilai akurasi rata-rata Co-occurence Matrix sebesar $66,5 \%$ dan nilai akurasi Geometric Moment Invariant sebesar $82,6 \%$. Hasil pengujian yang dilakukan dengan menurunkan jumlah data latih (training) cenderung menurun karena sistem semakin banyak data yang dilatih (training) maka semakin baik dalam proses klasifikasi motif batik begitu juga sebaliknya.

Tabel 3. Hasil Percobaan dengan Citra $512 \times 512$ pixel.

\begin{tabular}{llll}
\hline Jumlah Data Latih & Jumlah Data Uji & $\begin{array}{l}\text { Co-occurrence } \\
\text { Matrix }\end{array}$ & $\begin{array}{l}\text { Geometric Moment } \\
\text { Invariant }\end{array}$ \\
\hline 70 & 50 & $51 \%$ & $83 \%$ \\
\hline 50 & 50 & $64,4 \%$ & $79 \%$ \\
\hline
\end{tabular}


Pada percobaan dengan ukuran citra $512 \times 512$ pixel dan dengan jumlah data latih 70 serta jumlah data uji 50 nilai akurasi dengan menggunakan metode Co-occurence matrix adalah $51 \%$ hal ini mengalami penurunan dibandingkan pada percobaan dengan citra berukuran 256×256 pixel, dan dengan metode Geometric Moment Invariant pada percobaan citra berukuran

$512 \times 512$ nilai akurasinya $83 \%$ mengalami peningkatan dibandingkan dengan percobaan pada ukuran citra 256x256 pixel. Ketika jumlah citra latih(training) dan jumlah data uji 50 citra nilai akurasi dengan metode Co-occurence Matrix sebesar 64,4\% dan Geometric Moment Invariant sebesar $79 \%$. Pada akurasi Co-occurence Matrix mengalami penurunan sementara pada akurasi Geometric Moment Invariant tetap.

\section{Kesimpulan}

Berdasarkan hasil pengujian sistem maka dapat disimpulkan bahwa nilai akurasi dengan menggunakan metode Geometric Moment Invariant memiliki nilai lebih baik daripada akurasi dengan menggunakan metode Co-occurence Matrix. Nilai akurasi pada metode Geometric Moment Invariant tetap meskipun jumlah data latih dan data uji diturunkan. Sehingga untuk pengenalan motif batik Parang yang tergolong batik geometric, metode yang memiliki akurasi lebih baik adalah Geometric Moment Invariant.

\section{Daftar Pustaka}

[1] W. Eka Widya, "Klasifikasi Motif Batik Menggunakan Metode Transformasi Paket Wavelet," 2013.

[2] D. Putra, Pengolahan Citra Digital. Yogyakarta: Andi, 2010.

[3] T. Sergios, Pattern Recognition Second Edition. USA: Academic Press An Imprint Of Elsevier, 2003.

[4] A. Winarni, I. K. G. D. Putra, N. Ary, and E. Dewi, "Ekstraksi Ciri Warna dan Tekstur Untuk Temu Kembali Citra Batik," 2012. 